\title{
Malignant Pineal Region Germ Cell Tumor
}

National Cancer Institute

\section{Source}

National Cancer Institute. Malignant Pineal Region Germ Cell Tumor. NCI Thesaurus. Code C6767.

A malignant germ cell tumor that arises in the pineal region. Representative examples include germinoma, immature teratoma, choriocarcinoma, embryonal carcinoma and yolk sac tumor. 